\title{
6 Legal Pluralism and the Politics of Inclusion: Recognition and Contestation of Local Water Rights in the Andes
}

\author{
Rutgerd Boelens, ${ }^{1}$ Rocio Bustamante ${ }^{2}$ and Hugo de Vos $^{3}$ \\ ${ }^{1}$ Wageningen University and Research Centre, Wageningen, Netherlands; \\ e-mail: rutgerd.boelens@wur.nl; ${ }^{2}$ AGUA, San Simon University, Cochabamba, Bolivia; \\ e-mail: vhrocio@entelnet.bo; ${ }^{3}$ Freelance Researcher on Institutional Aspects of Natural \\ Resource Management in Latin America; e-mail: voswiz@versatel.nl
}

\begin{abstract}
In the Andean countries water has become a source of intense conflicts. Powerful water-interest groups intervene in local water systems and claim a substantive share of existing water rights, neglecting local agreements. These groups are often supported by neo-liberal water reform and privatization policies. This has led to peasant and indigenous mobilization and community action, grounded in shared rules and collective rights. Attempts to formally recognize local rights systems, however, have not guaranteed concrete protection in day-to-day realities, and the 'politics of recognition' have proved problematic. Legal and policy strategies that simply aim to 'include' local and indigenous rights systems - as 'distinct sets of rules and rights' - in the national frameworks are bound to fail. This chapter outlines some important conclusions of the Latin American WALIR (Water Law and Indigenous Rights Program) and critically examines the false policy dilemma of 'incorporation versus autonomy'. It concludes that the rightful critique to prevailing ethnocentric and universalistic approaches must not lead to equally simplistic praise for local autonomy or to cultural relativist reification of local rights systems. Critical analysis of the power relations that underpin both customary and official rights systems is crucial in order to improve local, national - as well as international - water laws. Local water rights and identities are given shape not by isolation or policies that reduce them to folkloric practices, or by legal and hierarchical subordination, but by conscious confrontation and meaningful communication among plural legal systems.
\end{abstract}

Keywords: Andean countries, water rights, water policies, privatization, collective action, legal pluralism, cultural politics, cultural identities, recognition, autonomy, incorporation.

\section{Introduction}

In the Andean region, particularly locally, collective water management systems are key to household and community production and reproduction strategies. As such they also sustain national livelihood. They comprise a dynamic and complex set of hybrid rules, rights and organizational forms: a tremendous diver- sity of context-defined 'sociolegal repertoires' or 'normative systems' can be found that generally combine non-local rule-making patterns with local organizational arrangements, frameworks of rights and rules for water distribution, system operation and maintenance. Thus, these rules systems have not come into being in a social vacuum, nor are they limited to isolated development: alongside physical and ecological Reform in Developing Countries (eds B. van Koppen, M. Giordano and J. Butterworth) 
conditions, their development is interwoven with the past and present history of cultural, political, economic and technological foundations of the Andean society. Despite their crucial importance, the threats that local water control and rights systems face are huge and ever-growing in a globalizing society.

The Water Law and Indigenous Rights Program (WALIR) ${ }^{1}$ aims to contribute to the support of local water management systems without reifying their form and contents - and critically analyses water rights and customary management systems in comparison with current national legislation and policy. This sheds light on conflicts and negative impacts of certain legislative measures and policy decisions. As an action research, exchange and advocacy programme, the initiative especially supports activities of local communities ${ }^{2}$ and inter-institutional platforms and networks to improve national water legislation and policies.

This chapter will elaborate some of the programme's key findings. Throughout the chapter we highlight the problems of legal and policy strategies that simply aim to 'include' or 'incorporate' local and indigenous rights systems - as 'distinct sets of rules and rights' - in the national frameworks. First, some basic features of Andean local water management dilemmas will be presented. Second, conceptual challenges of legal recognition strategies of local organizations will be analysed. Finally, it will discuss the 'politics of participation' in inclusionoriented water law and policy strategies. The intention is not to give definite answers but to clarify important questions and dilemmas (see Fig. 6.1).

\section{The Andean Context of Local Water Rights}

Peasant and indigenous water management systems contribute fundamentally to sustaining local livelihoods and national food security in the Andes (WALIR, 2003; Bustamante et al., 2004; Duran et al., 2006; Gelles, 2006). In most Andean countries, smallholder and mediumscale farmers of highland communities are responsible for the major part of national food production. However, in contrast to the important role local communities have in sustaining water management systems and food security, government policies are generally not supportive of them. Water rights in most regions of the Andes ${ }^{3}$ are largely concentrated in the hands of a few powerful stakeholders (Bustamante, 2002, 2006; Peña, 2004; Guevara and Armando, 2006; de Vos et al., 2006).

This unequal distribution has arisen not only because of historical reasons of colonial occupation and the encroachment of peasant and indigenous communities' water rights by conquistadores and haciendas, but also because of the contribution of contemporary state policies. For a long time, water policies have been focused on large-scale irrigation for hacienda or plantation agriculture in the lowlands and more recently on providing drinking water to the cities. Water is more and more viewed as an economic resource that has to be allocated to the most profitable economic use. The Chilean Water Policy, for example, highlights that: '... the allocation criterion for choosing between various requests will tend to be strictly economic, in practice, given that it is in the country's interest to allocate scarce water resources to those activities with the highest productivity per cubic meter ...' (ECLAC, 2005). Examples of modernist water policies benefiting predominantly the economically and politically well-to-do are abundant.

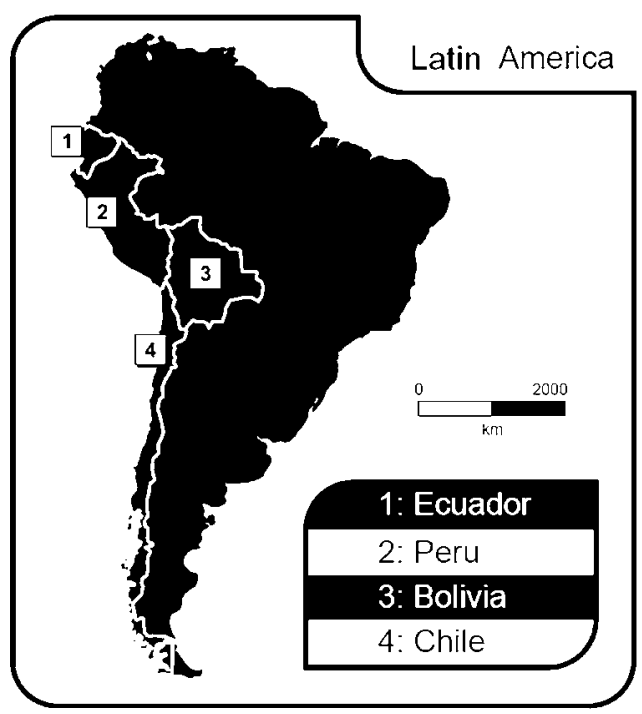

Fig. 6.1. Map of Latin America. 


\section{Illustration 1}

Water rights privatization in post-colonial Andean states has ancient roots. ${ }^{4}$ The implementation of the Choclococha project in Ica, Peru, for example, is illustrative of many of the attempts to undermine local communities' collective water rights, and formed part of privatization policies that had already started early in the 20th (and even late 19th) century, long before the current era of neo-liberalism (Oré, 1998; Mayer, 2002; Vos, 2002). Oré, for example, quotes an engineers' implementation report:

\begin{abstract}
The main reason for not having succeeded in developing irrigation in the Ica Valley up to now, through private or State efforts, is the existence of collective property systems in the pampas of Los Castillos. It is difficult to risk capital investment without having the backing in terms of security that the property rights of these valley lands will be obtained.
\end{abstract}

(Technical Report, Ica Technical Commission, 1936, in Oré, 2005)

In the Andean region throughout the 20th century, before the arrival of neo-liberal economists and planners of the last decade, hydraulic engineers and bureaucratic policy makers in particular have fiercely promoted the destruction of collective land and water ownership. For example, the collectively owned Los Castillos valley lands in Ica legally belonged to 114 indigenous families which, according to the engineers of the Ica Technical Commission and the Peruvian Water Directorate, were considered to be the 'major obstacle for the proper execution of the irrigation project'. The ownership characteristics of communal territories counteracted the free sale and lotización (parcelization) of these newly irrigated fields to individual owners. Therefore, the engineers first suggested and later firmly pressed the state to enforce a law that would allow the expropriation of the Pampa de Los Castillos. The landlords of the Ica Valley, eager to appropriate these large pampas, historically owned by the indigenous communities, strongly supported the engineers' proposals. Since they were labelled by the engineers as 'the ideal owners of the irrigation area', the landlords were installed as the new land and water property owners (Oré, 2005, cited in Boelens and Zwarteveen,
2005). Since then, numerous cases of other state and private sector water management interventions have had devastating consequences for locally managed community systems in the Andean highlands.

As in other parts of the world, increasing demographic pressure and the processes of migration, transnationalization and urbanization of rural areas are leading to profound changes in local cultures, forms of natural resources management and water rights frameworks. New, powerful water interest groups intervene in local water systems and claim a substantive share of existing water rights, often neglecting local rules and agreements. Further, in the context of neo-liberal water reform, national and international elites or enterprises commonly use both state intervention and new privatization policies to undermine and appropriate indigenous and community water rights.

In the last two decades, continuing poverty and exclusion have led to massive nationwide uprisings in Andean countries. Protests have questioned privatization plans, while indigenous and peasant groups have demanded to take part in policy making. These demands aim to offset their historical exclusion and promote policies grounded in an in-depth analysis of the potential and problems of local players in issues such as water management. Increasingly, the traditional struggle for more equal land distribution has been accompanied or replaced by collective claims for recognition of territorial rights, more equal water distribution and for the legitimization of local authorities and normative frameworks for water management (Beccar et al., 2002). Thereby, we see a certain shift from class-based to class-, gender- and ethnicitybased claims for water access and control rights. For example, indigenous groups are now claiming back both their water access rights and rulemaking authority, especially in countries such as Ecuador and Bolivia. Thereby, prevailing racist and gender-biased water policies are profoundly questioned and under fire, and water rights (claims and definitions) become arms in a struggle for recognition and social justice (Pacari, 1998; Albó, 2002; Bustamante, 2002; Palacios, 2002; Boelens and Zwarteveen, 2005; Bustamante et al., 2005; Baud, 2006; de Vos et al., 2006). Struggles thus increasingly transcend 
sectoral demands and involve networks of larger coalitions. The Bolivian example of the "water war' shows that collective struggles can result in participation in legislative processes.

\section{Illustration 2}

In 2000, the Central Valley of Cochabamba, Bolivia became a violent battlefield of protests against the state's plans to privatize the drinking water sector. The government signed a contract with a large foreign consortium and enacted a 'privatization support law' that gave an international company exclusive service and water rights in the district - including those of smaller systems in the peri-urban area and the rights to control aquifers. Directly after the international company had been awarded the concession, it significantly raised water fees before making any system improvement. A strong alliance of urban and rural water organizations protested: citizens protested against rising water rates, while local water committees and rural and indigenous organizations protested against infringement of their water access and control rights. After violent confrontations between these groups and the army, the government had to retract its decision and commit to amending all the law's articles to which the popular alliance objected (see Boelens and Hoogendam, 2002; Bustamante, 2002, 2006).

Following this so-called 'water war' the government, under pressure from international agencies, accepted indigenous, peasant and social organizations as participants in the elaboration of new regulations for drinking water and irrigation as part of the Consejo Interinstitucional del Agua (CONIAG) debates on the new (general) Water Law and Policy for the country. This resulted in the addressing of many previous concerns in a new 'Irrigation Law', in October 2004.

Recently, despite their generally threatened status and decline, there are growing opportunities for customary and indigenous cultures and rights systems. Most Andean countries have accepted international agreements and work towards constitutional recognition of ethnic plurality and multiculturalism. The ratification of the International Labour Organization (ILO) Convention 169 on Indigenous and
Tribal Peoples in Independent Countries is an important example. The last decade's change of constitutions in the Andean countries, ratifying the multicultural and plural roots and peoples that make up the countries, is another. However, when it comes to materializing such general agreements in more concrete legislation, such as water laws and policies, many difficulties arise. Context-specific local and indigenous forms of water management (especially decision-making rights to water control) tend to be denied or forbidden (Pacari, 1998; Yrigoyen, 1998; Bustamante, 2002; Gentes, 2002, 2005; Guevara et al., 2002; Palacios, 2002, 2003; Urteaga et al., 2003; Boelens et al., 2005). Before turning to the discussion of the 'politics of inclusion', first we will discuss some of the important conceptual and strategic problems of legal recognition.

\section{Conceptual Problems and Strategic Challenges}

Grassroots and popular action to counter rights encroachment and discrimination generally require clear messages and collectively shared goals and demands. However, programmes and platforms that aim to critically support the debate and process of recognition of local rights face several fundamental conceptual and strategic challenges. These are, for example, related to the following:

- Conceptualization of indigenous water rights and management rules.

- The concept of official recognition of local socio-legal repertoires (normative systems).

- The question of the effectiveness of legal (law-oriented) strategies for solving water conflicts and rights issues (Boelens, 2006).

\section{'Indigenous' water rights: their social and political construction}

Indigenous water user groups do not just struggle to reappropriate the above-mentioned water access rights, water management rules, water organizational forms and legitimate water authority: they also aim actively to construct their own counter-discourses on 'Andeanity' and 
'Indianity', and the policies to regulate water accordingly. Obviously, this dynamic, strategicpolitical struggle for counter-identification (selfdefinition) is not necessarily based solely on 'local' truths, rules, rights and traditions.

In the Andes and elsewhere, the denial of contemporary forms of indigenous water management is often combined with a glorification of the past (Flores Galindo, 1988; Assies et al., 1998; Gelles, 2000, 2006; Hale, 2002; Baud, 2006). We find a folkloristic attitude towards contemporary indigenous communities. Policies are oriented towards a non-existing image of 'Indianity', a stereotype; or towards the assimilation and destruction of indigenous water rights systems.

In the Andean region, the so-called 'Indians' were invented and the concept of 'indigenousness' was constructed by various racist currents, developmentalist paradigms and romanticized narratives, and by the indigenous peoples themselves. Divergent regimes of representation constructed images or projections of 'Andean identity' or 'indigenous cultures'. These projections refer either to the backwardness of the 'Indians' populations, who therefore should be assimilated into the mainstream culture, or to neo-positive, idealized images of 'real and pure Indians', isolated from cultural interaction and defenders of original positive human values. Indigenous groups have often adopted or contributed to the creation of these stereotypes, sometimes unreflectively, sometimes with clear ideological and political purposes (Salman and Zoomers, 2003; Boelens and Zwarteveen, 2005; Baud, 2006).

Portraying Andean and indigenous cultures as 'radically different', with pre-constituted identities and static cultural properties, reminds us of the past, essentialist philosophies and ideologies: they either created the 'noble savage' or tended, on the contrary, to generate the image of the backward, ignorant and violent Indian. Essentialization and reification generally deny or dichotomize colonial and post-colonial influences. They neglect the adaptability and hybridity of local cultures and management forms, and the way they necessarily interact with - and are influenced by - others; 'otherness' can be defined only in processes of confrontation, communication and, thus, interaction. Moreover, such approaches neglect the power structures that influence the process of cultural transformation, of both dominant and non-dominant groups. In the same way, those approaches that glorify lo andino (the Andean) tend to deny the existence of locally prevailing power structures that profoundly colour local (water) rights definitions and distributions.

This presents an important challenge to scholars, action researchers and NGOs: to refrain from naive participationism and to critically rethink intentions to support the so-called 'indigenous' knowledge, culture, rights, livelihoods and natural resources management. It also provides a challenge that water rights reform programmes need to face and shows partly how complex the objectives of rights-based empowerment initiatives are. For example, what is, or who is 'indigenous'? Is it possible to speak of specific 'indigenous' or 'Andean' cultures, communities, water management forms or socio-legal systems?

Often, what is called 'indigenous culture' combines elements from different origins Andean, as well as modern. As mentioned by Gelles (2000, p. 12), Andean culture and identity, therefore, are:

a plural and hybrid mix of local mores with the political forms and ideological forces of hegemonic states, both indigenous, Iberian and others. Some native institutions are with us today because they were appropriated and used as a means of extracting goods and labor by Spanish colonial authorities and republican states after Independence; others were used to resist colonial and postcolonial regimes.

'Indigenous' culture therefore has to be analysed as dynamic and adaptable to new challenges and contexts. ${ }^{5}$ The difficulties in defining what 'indigenous' means have also led to a shift in the debate toward using the broader concept of 'collective rights'. More recently, there has been a greater acceptance of the consideration of 'local' as a concept that better suits this kind of system, in reference to the fact that these normative frameworks have hybrid, contextualized and dynamic properties (see also von Benda-Beckmann et al., 1998).

\section{The plural and contradictory concept of 'recognition'}

'Legal recognition' is another notion that poses enormous conceptual problems and challenges, 
with important social and strategic consequences. 'Recognition' in contexts of legal pluralism is, by definition, many-faceted and generally ambiguous. In another paper ${ }^{6}$ we have discussed the dilemma regarding 'recognition of legal hierarchies', arguing that a distinction must be made between analytical-academic and political-strategic recognition.

In an analytical sense, legal pluralistic thinking does not establish a hierarchy (based on the supposedly higher moral values or degrees of legitimacy, effectiveness or appropriateness of a legal framework) among the multiple legal frameworks or repertoires that exist. In political terms, however, it is important to recognize that in most countries the existing, official legal structure is fundamentally hierarchical and consequently, in many fields state law may constitute a source of great social power - a fact that does not deny the political power that local socio-legal repertoires may have. Recognizing the existence of this political hierarchy and the emerging properties of state law in particular contexts offers the possibility to devise tools and strategies for social struggle and progressive change. In the discussion about 'recognition' as a way of giving legal pluralism a place in policyrelated issues, both the political-strategic and analytical-academic aspects of recognition combine.

(Boelens et al., 2002, p. 138)

The analytical aspect of recognition concentrates on the academic quest of knowing how plurality is ordered; the political aspect on whether and how this plurality is (or is to be) embedded in a political and legal hierarchy, based on existing power structures that establish the power and properties of the 'recognizers' and the ones to be 'recognized'.

Thus, instead of collective and unified claims, many questions arise in the debates and struggles for 'recognition', for example:

- How to define and delimit the domain of the validity of so-called indigenous rights systems? i.e. who is able to make claims? Considering the multi-ethnic compositions of most Andean regions and the dynamic properties of local normative frameworks it is difficult (or impossible) to come to uniform definitions. Would it be better to define rights systems in terms of exclusive geographical areas, traditional territories, or flexible culture and livelihood domains? Do indigenous peoples and their advocates claim recognition of just 'indigenous rights' (with all the conceptual and political-strategic dilemmas of the 'indigenous' concept), or do they also struggle for recognition of the broader repertoires of 'customary' and 'peasant' rights prevailing in the Andes? And what precisely is the difference in concrete empirical cases?

- Which recognition strategy is appropriate? Should indigenous peoples try to claim and defend legalization of their water access rights or try to legalize delimited frameworks of local water rights systems? Or should they rather claim the recognition of their autonomy to define, develop and enforce collective water control rights?

Since water access rights are increasingly under threat an important strategy might be first to claim the right to access, withdraw and usufruct the water - and assume that water management and control rights will follow once the material resource basis has been secured. Moreover, legalizing customary rights systems can be difficult. Although there are many dynamic, interacting and overlapping sociolegal repertoires there are no clear-cut, indigenous socio-legal frameworks. Therefore, it does not seem appropriate to recognize only the explicit and/or locally formalized indigenous property structures and water rights ('reference rights', often, but not always, written down), since these generally strongly deviate from the complex, dynamic local laws and rights in dayto-day practice. ${ }^{7}$ Claiming water control rights, instead of 'freezing' entire local rights systems in formal law, potentially has the advantage of granting autonomy to develop the rules and normative frameworks according to a dynamically changing context.

\section{The pitfalls and challenges of 'law-oriented strategies'}

One major conceptual and strategic-practical challenge stems from the difference between universally valid laws and context-dependent rights systems. National (positivist) legislation by definition claims that law must focus on uniform enforcement, general applicability and 
equal treatment of all citizens. At the same time, local and indigenous rights systems, by definition, address particular cases and diversity. How to deal with the conflict and fundamental difference between legal justice (oriented at 'right'-ness/generality) and diverse, local equity ('fair'-ness/particularity)?

Various forms of state legislation have recognized this fact when faced with losing its legitimacy in practice: official justice was perceived of as being 'unfair' for many specific cases. In many cases, a second set of principles (fairness) has been institutionalized by formulating 'special laws' (see Boelens et al., 2005). This was not to replace the set of positivist rightness rules, but to 'complement and adapt it'. In fact, it appeared that official legislation, 'justice', could often survive thanks to the 'fairness' and acceptability of common laws that had been incorporated. However, this institutionalized equity is a contradictio in terminis. It leads almost automatically to the ironical situation in which the set of common or customary rules, 'equity', itself becomes a general, formalized system and loses its pretensions of 'appropriateness', 'being acceptable' and 'doing justice' in particular cases (Schaffer and Lamb, 1981, cf. Boelens and Dávila, 1998).

These conceptual challenges raise several new questions. For example: how to avoid freezing of local dynamic systems by official recognition? Indigenous socio-legal repertoires make sense only in their own, dynamic and particular contexts, while national laws demand stability and continuity: how to avoid 'freezing' of customary and indigenous rights systems in static and universalistic national legislation in which local principles lose their identity and capacity for renewal, making them useless? How to avoid assimilation and subsequent marginalization of local rights frameworks when these are legally recognized? And how to avoid a situation in which only those 'customary' or 'indigenous' principles that fit into state legislation are recognized by the law, and the complex variety of 'disobedient rules' are silenced after legal recognition?

'Enabling' and 'flexible' legislation might solve the above problem. However, enabling legislation and flexible rights and rules often lack the power to actually defend local and indigenous rights in conflict with third parties. Thus, an important issue is how to give room and flexibility to diverse local water rights and management systems, while not weakening their position in conflict with powerful exogenous interest groups? Also, answers must be given to the question of what such legal flexibility means for 'internal' inequalities or abuses of power. If, according to the above dilemmas, autonomy of local rule development and enforcement is claimed for (instead of strategies that aim to legalize concrete, delimited sets of indigenous rights and regulations), how to face the existing gender, class and ethnic injustices that also form part of customary and indigenous socio-legal frameworks and practices? Answers to such questions necessarily point at directions where frameworks of collective rights and rule-making autonomy for local collectives are combined with the establishment of supra-local institutions and rules that need to guarantee the protection of individual and minority rights. ${ }^{8}$ These also need to offer opportunities for second-order conflict resolution and appellation in case local conflicts cannot be solved adequately.

Another important question that arises is how to balance the strategic importance and effectiveness of legal recognition with other struggles for water rights? Considering peasant and indigenous communities' lack of access to state law and administration, this question comes prominently to the fore: is legal recognition indeed the most effective strategy, or would it be better and more effective for peasant and indigenous communities to defend their own water laws and rights 'in the field'? Moreover, it often is not the state law as such that sets the rules of the game in peasant and indigenous communities, but hybrid complexes of various socio-legal systems. Formal rights and rules cannot act by themselves, and it is only the forces and relationships of society that can turn legal instruments into societal practice. In particular, social and technical water engineers, lawyers and other legal advocates have often overestimated the actual functionality or instrumentality of formal law and policies in local contexts. On the contrary, their legal anthropological colleagues have sometimes tended to underestimate the power of formal law, assuming that all conflicts are settled by means of local normative arrangements, without any influence from official regulations. 
Recent experience shows that legal recognition, just as legal misrecognition, tends to have an important effect on the daily lives of indigenous and peasant populations. For example, the neo-liberal water laws (in, e.g. Chile) or topdown instrumental water policies (in, e.g. Ecuador and Peru) have not only neglected customary and indigenous water-management forms but have also had concrete, often devastating, consequences for the poorest people in society. Because of the negative impact of application of official law, indigenous and grassroots organizations have fiercely engaged in the legal battle. It is important to consider here that efforts to gain legal recognition do not replace but rather complement local struggles in the field'. On both levels, there is political-strategic action to defend water access rights, define water control rights, legitimize local authority and confront powerful discourses. In the next section we will elaborate on how 'recognition struggles' at the local and national level shape the complex arena in which local water rights and customary laws confront uniform policies and politics of participation.

\section{Inclusion and Exclusion}

National water policies in the Andean countries and their translation in field practice mirror the political power and cultural hegemony of a dominant stakeholder group. ${ }^{9}$ Historically, this group has imposed rules, rights and regulations, and has controlled nation-building processes in previous centuries. As shown by Gelles (1998, 2000), state bureaucracies usually ignore indigenous models of resource management, not only because of the alleged superiority of 'modern' Western cultural forms and organization, but also because indigenous peoples are perceived as racially and culturally inferior (Gelles, 2000, pp. 9-10). ${ }^{10}$

Racist connotations stem from exclusionary politics from the Inca and Spanish colonial predecessors. In former days, indigenous property rights were taken away through violence, conquest, colonization and oppression. The Inca emperors and other indigenous leaders, as well as the kings, conquistadores and hacendados during the Spanish colonial period, differentiated themselves by excluding subordinated classes from resources, services and social life (Flores Galindo, 1988; Patterson, 1991; Mayer, 2002). Powerful groups were glorified through public displays, reinforcing the differentiation and social exclusion.

In the post-colonial area the opposite occurred. There was a move from 'exclusion' to 'inclusion' of indigenous peoples, from a discourse of racial (and thus 'natural' social) differentiation to one of equality (Boelens, 2006). Not the powerful authorities and landlords, but the peasant and indigenous communities and the common people, are made visible and, by means of a Foucauldian "power of equalizing normalization' ${ }^{11}$, they are individualized, classified and made 'cases' according to the ways that they do, or do not, fit the model. Yet, the powerful groups that benefit from this 'inclusive' power, as well as the new mechanisms and rules of subordination, now remain invisible. New irrigation legislation and state policies are often an expression of such post-colonial 'universality' and 'equality' discourses.

Throughout the Andes (as elsewhere), for example, irrigation technicians and development professionals have introduced virtually the same irrigation techniques, knowledge and norms (developed in Western research centres, universities and development enterprises). Nevertheless, they are not just 'imposed' in a top-down way. It is the indigenous peasants themselves who often ask for this same technology, to 'progress' and leave behind their traditional 'backward' technology, to become like the Western-oriented, modern farmers and to gain economic parity (cf. Escobar, 1995; van der Ploeg, 2003; Boelens, 2006).

Another clear example of normalization is found in the categorizing properties of neo-liberal market ideologies penetrating the Andean legal and policy frameworks regarding water management. Although the neo-liberal principles are imposed on Andean states by international institutions and national power groups, many of its basic concepts and dynamics have been adopted and internalized by Andean communities, penetrating and subtly transforming local management forms and often disarticulating indigenous water control. Communities are dispossessed through destruction of collective rights over resources. Recognition of private property rights has allowed rapid incorporation of land and 
water into the market system. Thus, the deployment of secular, rational, universally applicable irrigation models, supported nowadays by water management privatization ideologies, is a powerful means by which contemporary nation-states and private interest sectors extend their control.

Modernization and development discourses pretend to provide universal benefits but undermine balanced valuation of local beliefs and 'unruly' practices because any legitimization of these local norms calls into question both the state's and market ideology's supposed monopoly of rationality, efficiency and legitimate culture (Gelles and Boelens, 2003).

\section{The politics of participation}

The above analysis of new policies of 'integration', 'participation' and 'equality' raises some fundamental questions:

- If 'equality' is strived for, the question is: equal to what, equal to whom, equal to which model? The basic assumption in current Latin American water policies is, that 'progress' means: equality to occidental, technocentric and male-biased water management models. The concept of rational water management is interspersed with non-indigenous norms about efficiency, social security, effective organization, private ownership and economic functionality. In practice, indigenous peoples are forced to 'equalize': in other words, to adopt the norms and practices of white or mestizo water users, which most often run counter to local social relations and environment, and disintegrate local communities and identity.

- If 'inclusion' and 'participation' constitute the objective, the obvious question is: inclusion in what? Participation following whose objectives, visions and terms? In this respect, the Second World Water Forum (2000) concluded that: '.. there is a recurrent problem for indigenous peoples, who are often constrained to deal with vital issues on terms dictated by others. Traditional knowledge is seen as inferior in current political, legal, and scientific systems and therefore their arguments are discarded time and again by courts and other institutions.'
- Regarding the important current concepts of 'integrated' water management and 'integrated' policies, there seems to be a general consensus but the underlying central question is: who does the integration? Let us have a look at some common, inclusionoriented examples.

A first example draws on the Ecuadorian Licto Project. It illustrates problems of outsidedriven integration of indigenous communities in uniform, national legislation, organizational models and engineers' designs: ${ }^{12}$

\section{Illustration 3}

In Chimborazo province, Licto district, the Ecuadorian State intervened in the territory of 20 Andean communities to build an irrigation system and carry out an integrated development programme. The design was formulated in the country's capital, without user involvement. It disregarded community production systems and boundaries and imposed a classic, universal blueprint. The nationwide, uniform legal recipe dictated the organization of the system, which would strengthen bureaucratic power and new, artificial leaders, and weaken existing community structures and collective action - the only way to survive in this region. The state also imposed a model in which water rules and rights were established by uniform government rationality: those individuals who had land and pay fees obtained water rights. Indígena and campesino rationality, on the contrary, says: you cannot just buy rights. Those who contribute with labour or organizational capacities, and participate in the meetings, create water access and decision-making rights. Thereby, individual rights are derived from the collective ownership of infrastructure.

When the state agency, because of financial crises and lack of capacity, did not complete system construction, the indigenous communities took over its development with the help of a local NGO. They adapted design, management and water rights to local demands and capacities. Although many had no formal education or were illiterate, the means were developed to collectively discuss the project. Through interactive design, user-to-user training and the use of scale models, the design of infrastructure and 
water rights was linked. Combined literacy training and water management capacity building strengthened the position of female water users and female leaders, since they were to become involved in the management of the system. And in this region, characterized by male out-migration, they were the ones who were in charge of creation of and maintenance of water rights in the system. A system was developed which the communities themselves now manage, from the main level to the field level.

However, once the 20 indigenous communities had finished developing the system, with clear rules and rights and strong collective management, the state administration reappeared. It did not want to recognize local management, regulations and water rights. Simply because local rules were not sustained by national law, they were declared 'illegal'. The state agency intended to implement the universal 'Decentralization and Management Turnover' policy and 'include' the backward user communities in modern society. In practice, however, instead of legalizing the local system it claimed authority back, because: 'How can we hand it over if it is not in our hands?' Many projects and policies have effects in the field at variance with what theory predicts, and behind official arguments a power play is going on. Ecuadorian Water Law does not allow for local water rights and management principles, and destroys the variety of normative systems that do try to find particular solutions for diverse contexts.

\section{Illustration 4}

Another example is the inclusion of indigenous water communities - under certain limits and conditions - in current global water policy models. In Chile, all water users (including indigenous peoples) have become 'included' in the 1981 Water Code, dictating privatization of water rights. While ideological studies continue to praise the model, empirical field studies indicate the disintegration, in particular, of indigenous systems: the individualization of water rights has increased insecurity and disorganization - instead of decreasing insecurity, as neoclassical theory would wish (Bauer, 1997, 1998; Hendriks, 1998; Dourojeanni and Jouravlev, 1999; Castro, 2002).
According to Chilean legislation, decisions on water management are weighted according to actual possession of water rights. Right-holders with more 'water actions' (volumetric rights per time unit) have more decision-making power. This contrasts with indigenous management, where collective interests are negotiated according to the rule of 'one man, one vote'. Therefore, the Water Code has enabled a water rightsowning elite to effectively deny the interests of the majority (the group of poorer users) and impose their own playing rules (Hendriks, 1998). Moreover, since individual water property owners can make use of the water entirely according to their personal interests, Chile faces the problem of strong increase in water contamination, and individual property owners are not sanctioned for polluting their property. Often, indigenous communities and downstream cities bear the consequences (Bauer, 1997; Dourojeanni and Jouravlev, 1999).

Up till 2005, the 1981 Water Code did not request water rights owners to actually make use of their claims, or to pay concession fees. This made hoarding and speculation of water rights extremely attractive. When the new Water Code was enforced in 1981, most indigenous communities were left unaware of the need to officially register their century-old customary rights. One Mapuche leader said: 'The big landowners here in the area have registered the water rights in their names, and the Mapuches, for not knowing about the laws of the Chilean State, were left without possibilities to claim their rights' (Solón, 2003). Water rights that are not claimed, or the so-called 'unused rights', were allocated to those who presented official requests: powerful commercial companies, especially mining and power-generation enterprises and landlords (van Kessel, 1992; Hendriks, 1998; Dourojeanni and Jouravlev, 1999; Castro, 2002; Gentes, 2002).

Mapuche communities are furious about this. As one Mapuche leader phrases his anger:

The water sources that originate in the communities here have $98 \%$ of their trajectory on Mapuche territory, but the owner of the water is a landlord who lives in the city. He bought the water from the state, and nobody can use it. We cannot use it for irrigation, not even for drinking water, because the water has been bought. But the water was born in and flows through 
Mapuche communities, and no one of the Mapuches was aware of the need for official recognition when this person registered the water rights on his name. No one of us was consulted and no Mapuche ever knew of the existence of this law.

(Solón, 2003)

It is not only the neo-liberal assumption that (market) information is freely available to everyone that is challenged here, but also the very basis for rights claims. Mapuche communities strongly feel that the water is theirs, because they have been using it for centuries and because it flows through their territory, whereas the Water Code demands official registration as a first basis for rights allocation (Boelens and Zwarteveen, 2005).

To counteract the negative consequences of the Water Code for indigenous communities, Chile enacted a new law in 1993: the Ley Indígena (Indigenous Law). Although it was meant to support indigenous populations in their defence of what was left of their territorial rights and livelihoods, in practice it was difficult to enforce. The fact that it is a 'special law' only applicable for (and within) a 'special group of the national population' (called a 'minority'), and the costly and time-consuming procedures has left most of the indigenous claims unanswered. Moreover, the Indigenous Law has proved to be extremely weak as a legal tool, whenever indigenous communities had to face the powerful Water and Mining Codes that are called upon by the country's water-owning elites.

This relates also to a recurrent problem of universal or national policy models: their validity is based on theoretical models and paradigms, but they usually fail to look at human suffering and internal contradictions in the field. Currently, the democratic government and civil society institutions have succeeded in changing some of the articles that most threaten the rights of indigenous communities and user collectives. Nevertheless, such attempts at changing the law towards social and environmental improvements meet with fierce resistance of powerful actors who defend their accumulated, private water rights.

The inclusion of local and indigenous rights frameworks in bureaucratic, state-oriented models or neo-liberal, market-oriented models is not always based on brutal impositions. On the contrary, water reforms are presented as merely neutral and technical interventions aimed at better controlling and managing the water crisis. It is suggested that such interventions do not fundamentally alter or influence existing social and political relations. And to peasant and indigenous water user communities it is explained that flows of money and water follow universal, scientific laws and that human beings share the same aspirations and motives as everywhere. Such inclusion-oriented policies establish a universal rationality based on a 'natural' truth and 'objective' criteria for optimizing efficiency and water management (Boelens and Zwarteveen, 2005).

Peasant and indigenous movements point at the fact that this is a false representation of reality: the proposed water reforms are not just slight modifications that basically leave existing social relations intact, but they involve quite radical changes in social and political structures in which water management is embedded. The proposed ways in which water is to be owned, distributed and managed imply fundamental change, and so do the ways in which different water users relate to each other. If such universal modernization policies are implemented, relations are increasingly dictated by extracommunal laws, institutions and markets (Boelens and Zwarteveen, 2005).

In Bolivia, attempts to 'modernize' the water sector led to such widespread protests that the government was forced to allow real participation of protesting groups in the policy reform process. The illustration below shows not only that state politics of inclusion are contested but how the definitions of this 'inclusion' were challenged by the water user organizations. It was only through continuous pressure that their voices became officially recognized in official law.

\section{Illustration 5}

Bolivia is a country, different from other countries in the Andes, where the state has been very weak and so far almost absent in water management issues. As Larson (1992) observes, it was the colonial policy (18th century) to give private possession of land and water to individuals, in order to collect taxes. This policy was formalized by the subsequent 
republican government (through the so-called Leyes de exvinculacion in 1874). Much of the Pueblos de Indios (communally owned land) was assigned as private property to indigenes living in those territories and allowed a very active market by the beginning of the 20th century. This practice was resisted in the Altiplano region, especially by Aymara communities that used legal strategies to defend the communal or collective character of the land, preserved up to date in some places. As a result of the non-involvement of state bureaucracy in water resources management and regulation, water control in the rural areas, including that in peri-urban and sometimes even in urban areas, is usually autonomous and independent.

It was only very recently and as a result of external pressure that the Bolivian government started its 'politics of inclusion', aiming at a process of deregulation and privatization in the water sector, mainly relating to drinking water and irrigation. However, neo-liberal policies have been difficult to implement because they have led to conflicts and protests. After the 'water war' in the year 2000, popular resistance to uniform inclusion policies and politics led to a shift in policy-making processes, towards dialogues and consultation. Several indigenous and representative groups participated in the formulation process of the Drinking Water and Sanitation Services Act and Bylaws and the Irrigation Normative design process (2001), which recently resulted in the approval of the Irrigation Law (October 2004). Some features of this new legislation are:

- Creation of different types of rights over water resources and over water services provision.

- Recognition of indigenous and community rights to water and water services, under the legal figure of a registrar. A community receives collective and indefinite rights.

- Setting up of new institutional bodies to deal with water resources allocation, conflict resolution, water management at catchment scale, etc. regarding drinking water and sanitation (Comisiones de Registros y Licencias) and irrigation (SENARI and SEDERI). The new organizations will have representatives from local, indigenous and peasant water organizations.
- Respect for the local, indigenous and peasant water management norms: 'uses and customs' and local authorities.

The consultation process - even though this was not just through consensus building, but more particularly due to pressure by social action groups - meant significant progress in recognition of local, indigenous and communities' rights. However, this apparent openness of the state to 'give recognition' to customary rights places local water organizations in a dilemma. They are trying, on the one hand, to get their water rights and water control forms legally protected and, on the other, to maintain their autonomy and self-management. The question remains whether these new regulations will really empower local water organizations or only legitimize state intervention in an area where, previously, its presence was minimal.

\section{Justice and the right to be different}

The 'politics of inclusion' face fierce resistance by different social movements that demand alternative strategies of natural resources use and maintenance. While such movements are motivated by a range of concerns, such as social justice, the environment, 'right to livelihood' or ethnic identity, they all make claims for more equitable and just access to natural resources. All centre on the question of property rights, because whoever controls property rights controls the processes of resource extraction and environmental change. For example, in Ecuador and Bolivia, the countries in South America with the largest indigenous populations, well-organized social movements have been able to change national-level debates in water reform. CONAIE (1996) made its own proposal for a new water law, which included: (i) demands on resisting privatization of water resources; (ii) continued public and community control in water allocation, recognition of cultural and social rights; and (iii) representation of users, indigenous and peasant organizations, within the institutional framework for water management. In 1998, some of these proposals were recognized in constitutional reforms. However, up to now, proposed 
reforms of the actual water law have not been accepted in Congress.

In Bolivia, indigenous and peasant confederations also proposed an alternative water law and a new water reform agenda. This proposal emphasized social rather than just economic aspects of water and community water rights. As elaborated above, implemented in 2004, the drinking water legislation and a new irrigation law have begun to recognize some of the concerns of social organizations in relation to water rights, participation and social control. The newly installed indigenous President Evo Morales (2006) and the MAS government (Movimiento al Socialismo) plan to change the Water Law and install a Ministry of Water to enhance more equitable distribution of benefits and burdens, and to legally recognize and regularize the local and customary water rights of indigenous and peasant communities. In other Andean countries, indigenous, peasant and other grass-roots groups are also pressing for more equitable water rights distribution. ${ }^{13}$

These struggles not only concern control over water but also, and importantly, over the right to define what a water right entails. Fundamentally, the water rights struggle includes the following key issues: (i) access to water and infrastructure; (ii) rules and obligations regarding resource management; (iii) the legitimacy of authority to establish and enforce rules and rights; and (iv) the discourses and policies to regulate the resource. And it is precisely the authority of indigenous and peasant organizations that is increasingly being denied, their water usage rights that are being cut off and their control over decision-making processes that is being undermined.

It is, in particular, local peasant and indigenous water users' collectives that are facing both the water-scarcity crisis and the policies developed to counter that crisis. Paradoxically, it is precisely the ones with solutions - the producers of local livelihood and national food security, who developed a variety of water rights and management systems in order to adapt them to the multiple local constraints and opportunities - who are being denied and suffer most from the devastating consequences of 'modern water approaches'. But, if current cultural politics and policies of 'inclusion' constitute the problem, the solution can never be to go back to 'exclusion'. Participation, yes, but with a different rights approach, based on the self-perception of them being right-holders and not just users, taking critically into account that peasant and indigenous communities (and other local groups) want to 'participate' on their own terms. On the one hand, there is a general demand for greater justice and equality regarding the unequal distribution of decision-making power, water and other water-related benefits and, on the other, there are the demands for internal distribution to be based on autonomous decisions, locally established rights and principles and local organizational forms for water control that reflect the diverse strategies and identities found in local communities today.

\section{Conclusions}

Triggered by population pressure, water monopolization practices, class- and ethnicitybiased intervention policies and climate change, among others, the growing scarcity of water has caused intensified conflicts over the resource in the Andean region. But it also has led to mobilization and community or intercommunity action, grounded in shared rules and collective rights. In various instances, such mobilization has effectively resulted in increased recognition of local collective rights and more equitable access to the resource. Formal recognition, however, has not been proved to guarantee concrete protection of local water management systems in the day-today realities, against outside claims and transfer of water to economically powerful sectors. 'Inclusion' and 'integration' appear to be complex rights matters.

It is common in academic and policy circles that the question of local rights (and identity) recognition is placed as a false dilemma, "incorporation versus autonomy': either accepting the universalized, liberal standards of rationality, efficiency, human rights, justice and order or recognizing and celebrating local diversity and rule-making whatever the outcome may be. However, the issue is not so much a matter of respecting 'otherness', if this is presented as 'isolated and radically different normative systems', entirely 'distinct rules and rights' and 
'pre-constituted, static identities'. Rightful critique to ethnocentric, universalistic or rigid positivist approaches should not mislead us to reify local rules and rights autonomy, and give freeway to a cultural relativist approach or, worse, a revival of the theories that essentialize the 'noble savage', assuming that 'indigenous' is equal to 'good' and 'local' is presented as necessarily 'better' and 'more just' than national or international. ${ }^{14}$

This positioning not only risks the legitimization and legalization of local class, ethnic and gender injustices but also misrepresents the dynamic nature of water culture, water rights and the hybrid forms taken by water control and organization in practice. Essentializing and stereotyping of local water norms, rights and cultures, be it in law, policies, intervention strategies or theoretical reflection, deny the very existence of interaction among socio-legal systems and thereby equally deny the right to self-recreation (and improvement) of diverse normative systems, always and necessarily in contact with 'otherness'.

Opportunities for and openness to mutual critique and self-critique are essential for living law systems and their re-creation - an equally important message for formal, national law making. Critical analysis of the power relations that underpin these systems, thus, is crucial in order to improve both local, national and international water laws and rights. Local water rights and identities are given shape not by reification, isolation or folkloric policies but by confrontation and communication in an interlegality approach. This calls for proactive, contextualized and power-critical strategies that enhance interdisciplinarity rather than multidisciplinarity, interculturality rather than multiculturalism, and inter-legality rather than 'multilegalism'.

\section{Endnotes}

1 WALIR is a collaborative programme coordinated by the Wageningen University (WUR/IWE) and the United Nations Economic Commission for Latin America and the Caribbean (UN/ECLAC) and implemented in cooperation with counterpart institutions in Bolivia, Chile, Ecuador, Peru, Mexico, France, Netherlands and the USA (http:// www.eclac.cl/drni/proyectos/walir/). The counterparts work with a broad group of participants: institutions at international, national and local levels.

2 Local communities include not only peasants and indigenous groups but also other local organizations.

3 Bolivia is an exception to this: indigenous, peasant and local organizations have managed relatively well to keep control over their water resources.

4 This illustration is taken from Boelens and Zwarteveen, 2005 and elaborated in Oré, 2005.

5 As a reaction, in Bolivia, for instance, some social organizations claim now to be not indigenous but 'first peoples' nations', also being a clear way to challenge the state's authority (that was created only in the 19th century) over natural resources.

6 'Taking "recognition" as a point of departure implies that there is a "recognizing party" and a "party being recognized". This would put us in the kind of state-biased position in which matters are decided upon according to a state-determined hierarchy of legal systems' validity. Such a position, needless to say, would invalidate the insights derived from attention to legal pluralism. On the other hand, it is important to be aware of the possible opportunities involved in (state) recognition, taking into account and taking seriously the fact that many local groups of resource users (and right-holders), ethnic and other minorities actively aspire and strive for this form of recognition' (Boelens et al., 2002; see also von BendaBeckmann, 1996; Roth, 2003; Roth et al., 2005).

7 These 'rights in action' emerge in actual social relationships and inform actual human behaviour, but are less 'tangible' (cf. Rudolf Stavenhagen and Diego Iturralde eds., 1990; Stavenhagen, 1994; von Benda-Beckmann et al., 1998; Gerbrandy and Hoogendam, 1998; Bruns and MeinzenDick, 2000; Boelens and Doornbos, 2001; WALIR, 2002; Hendriks, 2004; van Koppen and Jha, 2005; Getches, 2006).

8 Many constitutions have set limits on customary systems, stating that they can be valid only if they do not run contrary to the official laws and regulations of the country. In other cases, the limits are set by human rights principles.

9 This section is largely based on and taken from Gelles and Boelens (2003).

10 This bureaucratic irrigation tradition has been especially powerful in countries such as Peru and Ecuador. As Lynch (1993) and Zwarteveen and Boelens (2006) have shown, its devaluation of particular water use actors extends to women, as the gender discrimination found in the field and in irrigation offices is part and parcel of the bureaucratic tradition (cf. Vera, 2004; Bennet et 
al., 2005; Bustamante et al., 2005; Zwarteveen and Bennet, 2005).

11 'This power is exercised rather than possessed; it is not a "privilege", acquired or preserved, of the dominant class, but the overall effect of its strategic positions - an effect that is manifested and sometimes extended by the position of those who are dominated' (Foucault, 1978).

12 Based on the chapter 'Recipes and resistance. Peasants' rights building and empowerment in the Licto irrigation system, Ecuador' of the book Water Rights and Empowerment (Boelens and Hoogendam, 2002).

13 The difference is that, in countries like Colombia and Chile, indigenous groups are considered as minorities, with special rights. Therefore, it was easier to enact and implement special laws for indigenous groups; this is not as easy in Bolivia and Ecuador, where more than $50 \%$ of the population is considered to be indigenous (see also Van Cott, 2000).

14 Paradoxically, both approaches commonly lead to subordination by incorporation and inclusion. The first aims to homogenize and 'equalize' all water rights and cultures according to the illuminating model of (neo-)liberalism and modernity, in which all actors and resources should be included. The second, although pressing for local autonomy, tends to codify, freeze and subordinate all non-official rights systems under the umbrella of national law that would 'protect local rights and cultures'.

\section{References}

Albó, X. (2002) Iguales Aunque Diferentes. CIPCA, La Paz.

Assies, W., van der Haar, G. and Hoekema, A. (eds) (1998) The Challenge of Diversity. Indigenous Peoples and Reform of the State in Latin America. Thela Thesis Publishers, Amsterdam.

Baud, M. (2006) Ethnicity, identity politics and indigenous movements in Andean history. In: Agua y Derecho. Políticas Hídricas, Derechos Consuetudinarios e Identidades Locales. WALIR - IEP, Lima.

Bauer, C. (1997) Bringing water markets down to earth: the political economy of water rights in Chile, 1976-1995. World Development 25 (5), 639-656.

Bauer, C. (1998) Slippery property rights: multiple water uses and the neoliberal model in Chile, 1981-1995. Natural Resources Journal 38, 110-155.

Beccar, L., Boelens, R. and Hoogendam, P. (2002) Water rights and collective action in community irrigation. In: Boelens, R. and Hoogendam, P. (eds) Water Rights and Empowerment. Van Gorcum, Assen, Netherlands, pp. 1-21.

Bennet, V., Dávila-Poblete, S. and Nieves Rico, M. (eds) (2005) Opposing Currents. The Politics of Water and Gender in Latin America. University of Pittsburgh Press, Pittsburgh, Pennsylvania.

Boelens, R. (2006) Local rights and legal recognition: the struggle for indigenous water rights and the cultural politics of participation. In: Boelens, R., Chiba, M. and Nakashima, D. (eds) Water and Indigenous Peoples. WALIR-UNESCO, UNESCO, Paris, pp. 38-45.

Boelens, R. and Dávila, G. (eds) (1998) Searching for Equity. Conceptions of Justice and Equity in Peasant Irrigation. Van Gorcum, Assen, Netherlands.

Boelens, R. and Doornbos, B. (2001) The battlefield of water rights. Rule making amidst conflicting normative frameworks in the Ecuadorian highlands. Human Organization 60 (4), 343-355.

Boelens, R. and Hoogendam, P. (eds) (2002) Water Rights and Empowerment. Van Gorcum, Assen, Netherlands.

Boelens, R. and Zwarteveen, M. (2005) Anomalous water rights and the politics of normalization. Water control and privatization policies in the Andean region. In: Roth, D., Boelens, R. and Zwarteveen, M. (eds) Liquid Relations. Contested Water Rights and Legal Complexity. Rutgers University Press, New Brunswick, New Jersey and London.

Boelens, R., Roth, D. and Zwarteveen, M. (2002) Legal complexity and irrigation water control: analysis, recognition and beyond. Paper for the International Congress of Legal Pluralism, 7-10 April 2002, Chiang Mai, Thailand.

Boelens, R., Gentes, I., Guevara, G., Armando, J. and Urteaga, P. (2005) Special law: recognition and denial of diversity in Andean water control. In: Roth, D., Boelens, R. and Zwarteveen, M. (eds) Liquid Relations. Contested Water Rights and Legal Complexity. Rutgers University Press, New Brunswick, New Jersey and London.

Bruns, B.R. and Meinzen-Dick, R.S. (eds) (2000) Negotiating Water Rights. Vistaar Publications, New Delhi, India and IT Publications, London. 
Bustamante, R. (2002) Legislación del Agua en Bolivia. WALIR Research Vol. 2, Centro Agua, UN/CEPAL and Wageningen University, Wageningen University, Wageningen, Netherlands.

Bustamante, R. (2006) Normas Indígenas y Consuetudinarias Sobre la Gestión del Agua en Bolivia. WALIR Research Vol. 10, Centro Agua, UN/CEPAL and Wageningen University, Wageningen University, Wageningen, Netherlands.

Bustamante, R., Butterworth, J., del Callejo, I., Duran, A., Herbas, D., Hillion, B., Reynaga, M. and Zurita, G. (2004) Multiple sources for multiple uses: Household case studies of water use around Cochabamba, Bolivia. Available at http://www.irc.nl/content/view/full/8031

Bustamante, R., Peredo, E. and Udaeta, M.E. (2005) Women and the 'water war' in the Cochabamba valleys. In: Bennett, V., Dávila-Poblete, S. and Rico, M.N. (eds) Opposing Currents. The Politics of Water and Gender in Latin America. University of Pittsburgh Press, Pittsburgh, Pennsylvania, pp. 72-90.

Castro, M. (2002) Local norms and competition for water in Aymara and Atacama communities, Northern Chile. In: Boelens, R. and Hoogendam, P. (eds) Water Rights and Empowerment. Van Gorcum, Assen, Netherlands, pp. 187-201.

CONAIE (the Confederation of Indigenous Nationalities of Ecuador) (1996) Propuesta Ley de Aguas. CONAIE, Quito.

de Vos, H., Boelens, R. and Bustamante, R. (2006) Formal law and local water control in the Andean region: a fiercely contested field. International Journal for Water Resources Development 22 (1), 37-48.

Dourojeanni, A. and Jouravlev, A. (1999) El Código de Aguas en Chile: entre la ideología y la realidad. Serie Recursos Naturales e Infraestructura No. 3, CEPAL, Santiago de Chile.

Duran, A., Herbas, D., Reynaga, M. and Butterworth, J. (2006) Planning for Multiple Uses of Water: Livelihood Activities and Household Water Consumption in Peri-urban Cochabamba. Bolivia. Centro AGUA, Cochabamba, Bolivia.

ECLAC (United Nations Economic Commission for Latin America and the Caribbean) (2005) Circular No. 22 of the Network for Cooperation in Integrated Water Resource Management for Sustainable Development in Latin America and the Caribbean, August 2005. ECLAC, Santiago de Chile.

Escobar, A. (1995) Encountering Development. The Making and Unmaking of the Third World. Princeton University Press, Princeton, New Jersey.

Flores Galindo, A. (1988) Buscando un Inca. Identidad y Utopia en los Andes. Editorial Horizonte, Lima.

Foucault, M. (1978) Discipline and Punish: the Birth of the Prison. Pantheon Books/Random House, New York.

Gelles, P.H. (1998) Competing cultural logics: state and 'indigenous' models in conflict. In: Boelens, R. and Dávila, G. (eds) Searching for Equity. Van Gorcum, Assen, Netherlands, pp. 256-267.

Gelles, P.H. (2000) Water and Power in Highland Peru: the Cultural Politics of Irrigation and Development. Rutgers University Press, New Brunswick, New Jersey.

Gelles, P.H. (2006) Indigenous peoples, cultural identity, and water rights in the Andean nations. In: Agua $y$ Derecho. Políticas Hídricas, Derechos Consuetudinarios e Identidades Locales. WALIR - IEP, Lima.

Gelles, P.H. and Boelens, R. (2003) Water, community and identity: the politics of cultural and agricultural production in the Andes. In: Salman, T. and Zoomers, A. (eds) Imaging the Andes: Shifting Margins of a Marginal World. Aksant, Amsterdam.

Gentes, I. (2002) Estudio de la Legislación Oficial Chilena y del Derecho Indígena a los Recursos Hídricos. WALIR Research Vol. 2, CEPAL and Wageningen University, Santiago de Chile.

Gentes, I. (2005) Estudio Sobre Marcos Normativos Indígenas y Consuetudinarios Referente a la Gestión del Agua en Chile. WALIR Research Vol. 5, CEPAL and Wageningen University, Santiago de Chile.

Gerbrandy, G. and Hoogendam, P. (1998) Aguas y acequias. PEIRAV - Plural Editors, Cochabamba, Bolivia.

Getches, D. (2006) Indigenous Rights and Interests in Water under USA Law. WALIR Research Vol. 6, University of Colorado at Boulder, Colorado, UN/CEPAL and Wageningen University. Wageningen University, Wageningen, Netherlands.

Guevara, G. and Armando, J. (2006) Official water law versus peasant and indigenous rights in Peru. In: Boelens, R., Chiba, M. and Nakashima, D. (eds) Water and Indigenous Peoples. WALIR-UNESCO, UNESCO, Paris.

Guevara, A., Vera, J., Urteaga, P., Vera, I. and Zambrano, G. (2002) Estudio de la Legislación Oficial Peruana sobre la Gestión Indígena de los Recursos Hídricos. WALIR Research Vol. 2, Wageningen University, Wageningen, Netherlands and UN CEPAL/ECLAC, Santiago de Chile, pp. 101-131.

Hale, C.R. (2002) Does multiculturalism menace? Governance, cultural rights and the politics of identity in Guatemala. Journal of Latin America Studies 34 (3), 485-524.

Hendriks, J. (1998) Water as private property. Notes on the case of Chile. In: Boelens, R. and Dávila, G. (eds) Searching for Equity. Van Gorcum, Assen, Netherlands, pp. 297-310. 
Hendriks, J. (2004) Legislación de aguas y gestión de sistemas hídricos en la región Andina. WALIR Position Paper, International Workshop on Collective Rights, Local Water Management and National Legislation, October 2004, WALIR, Quito.

Larson, B. (1992) Colonialismo y Transformación Agraria en Bolivia - Cochabamba 1500-1900. CERES/HISBOL, La Paz.

Lynch, B.D. (1993) The bureaucratic tradition and women's invisibility in irrigation. Proceedings of the 24th Chacmool Conference, University of Calgary Archeological Association, Alberta, Canada, pp. 333-342.

Mayer, E. (2002) The Articulated Peasant: Household Economies in the Andes. Westview Press, Boulder, Colorado.

Oré, M.T. (1998) From agrarian reform to privatization of land and water: the case of the Peruvian coast. In: Boelens, R. and Dávila, G. (eds) Searching for Equity. Van Gorcum, Assen, Netherlands, pp. 268-278.

Oré, M.T. (2005) Agua, Bien Común y Usos Privados. Riego, Estado y Conflictos en La Achirana del Inca. Wageningen University, Wageningen, Netherlands and WALIR and PUCP, Lima.

Pacari, N. (1998) Ecuadorian water legislation and policy analysed from the indigenous-peasant point of view. In: Boelens, R. and Dávila, G. (eds) Searching for Equity. Van Gorcum, Assen, Netherlands, pp. 279-287.

Palacios, P. (2002) Estudio Nacional de la Legislación Oficial y los Marcos Normativos Consuetudinarios Referente a la Gestión Indígena de los Recursos Hídricos. WALIR, CEPAL, Lima and Wageningen University, Wageningen, Netherlands.

Palacios, P. (2003) Estudio Sobre Marco Normativos Indígenas y Consuetudinarios. WALIR Research Vol. 2, CEPAL, Quito and Wageningen University, Wageningen, Netherlands.

Patterson, T. (1991) The Inka Empire: the Formation and Disintegration of a Precapitalist State. Berg Press, New York.

Peña, F. (ed.) (2004) Los Pueblos Indígenas y el Agua: Desafíos del Siglo XXI. El Colegio de San Luis, WALIR, IMTA. Obranegra Editores, Mexico D.F. and Bogotá.

Roth, D. (2003) Ambition, regulation and reality. Complex use of land and water resources in Luwu, South Sulawesi, Indonesia. PhD dissertation, Wageningen University, Wageningen, Netherlands.

Roth, D., Boelens, R. and Zwarteveen, M. (eds) (2005) Liquid Relations. Contested Water Rights and Legal Complexity. Rutgers University Press, New Brunswick, New Jersey and London.

Salman, T. and Zoomers, A. (eds) (2003) Imaging the Andes: Shifting Margins of a Marginal World. CEDLA, Aksant, Amsterdam.

Schaffer, B. and Lamb, G. (1981) Can Equity Be Organized? Equity, Development Analysis and Planning. Institute of Development Studies, Sussex University, Brighton, UK.

Solón, P. (2003) La Sangre de la Pachamama. Documentary. Fundación Solón, La Paz.

Stavenhagen, R. (1994) Indigenous rights: some conceptual problems. In: Assies, W. and Hoekema, A. (eds) Indigenous Peoples. Experiences with Self-Government. University of Amsterdam and IWGIA, Copenhagen.

Stavenhagen, R. and Iturralde, D. (eds) (1990) Entre la ley y la Costumbre. El Derecho Consuetudinario Indígena en América Latina. Instituto Indigenista Interamericano e Instituto Interamericano de Derechos Humanos, Mexico City.

Urteaga, P., Vera, I. and Guevara, A. (2003) Estudio Sobre las Reglas y Regulaciones Indígenas y Consuetudinarias para la Gestión de los Recursos Hídricos en el Perú (draft version). WALIR, Wageningen University, Wageningen, Netherlands and UN CEPAL, Lima/Santiago.

Van Cott, D.L. (2000) The Friendly Liquidation of the Past: the Politics of Diversity in Latin America. Pitt Latin American Series, Pittsburg University Press, Pennsylvania.

van Kessel, J. (1992) Holocausto al Progreso: Los Aymarás de Tarapacá. Hisbol, La Paz.

van Koppen, B. and Jha, N. (2005) Redressing racial inequities through water law in South Africa: interaction and contest among legal frameworks In: Roth, D., Boelens, R. and Zwarteveen, M. (eds) Liquid Relations. Contested Water Rights and Legal Complexity. Rutgers University Press, New Brunswick, New Jersey.

van der Ploeg, J.D. (2003) The Virtual Farmer. Van Gorcum, Assen, Netherlands.

Vera, J. (2004) 'Cuanto más doy, más soy ...' Discursos, normas y género: la institucionalidad de las organizaciones de riego tradicionales en los Andes del sur peruano. In: Peña, F. (ed.) Los Pueblos Indígenas y el Agua: Desafios del Siglo XXI. El Colegio de San Luis, WALIR, IMTA. Obranegra Editores: Mexico D.F. and Bogotá.

von Benda-Beckmann, F. (1996) Citizens, strangers and indigenous peoples: conceptual politics and legal pluralism. Law and Anthropology 9, 1-43. 
von Benda-Beckmann, F., von Benda-Beckmann, K. and Spiertz, J. (1998) Equity and legal pluralism: taking customary law into account in natural resource policies. In: Boelens, R. and Dávila, G. (eds) Searching for Equity. Van Gorcum, Assen, Netherlands, pp. 57-69.

Vos, J. (2002) Metric matters. Water control in large-scale irrigation in Peru. PhD thesis, Wageningen University, Wageningen, Netherlands.

WALIR (Water Law and Indigenous Rights Program) (2002) Indigenous Water Rights, Local Water Management, and National Legislation. WALIR Research Vol. 2, CEPAL-United Nations, Santiago de Chile and Wageningen University, Wageningen, Netherlands.

WALIR (Water Law and Indigenous Rights Program) (2003) Análisis de la Situación del Riego en la República del Ecuador. Misión de Consultoría (Hendriks, Mejía, Olazával, Cremers, Ooijevaar, Palacios), CONAM-BID, Quito.

Yrigoyen, R. (1998) The constitutional recognition of indigenous law in Andean countries. In: Assies, W., Van der Haar, G. and Hoekema, A. (eds) The Challenge of Diversity. Thela Thesis Publishers, Amsterdam.

Zwarteveen, M. and Bennet, V. (2005) The connection between gender and water management. In: Bennett, V., Dávila-Poblete, S. and Rico, M.N. (eds) Opposing Currents. The Politics of Water and Gender in Latin America. University of Pittsburgh Press, Pittsburgh, Pennsylvania, pp. 13-29.

Zwarteveen, M. and Boelens, R. (2006) Rights, meanings and discourses. Gender dimensions of water rights in diverging regimes of representation in the Andes. In: Lahiri-Dutt, K. (ed.) Fluid Bonds: Views on Gender and Water. Stree, Kolkata, India. 